\title{
Regional Features of Card Payments in Hungary*
}

\author{
László Kajdi - István Nemecskó
}

In retail trade, card payments currently represent the most important alternative to cash, which is less favourable from a social perspective in the long run. Earlier studies typically focused on the development opportunities of Hungarian electronic payments at the country level only. This study uses previously unavailable data to examine the regional features of card payments in Hungary, identifying the factors influencing their infrastructure and use. The results show that in smaller settlements the acceptor network is less developed and card ownership is lower, while in terms of regions, the situation looks bleaker in Northern Hungary and Central Transdanubia with respect to the POS network, and in the counties of the Great Plain this is the case in relation to card ownership. Card use is significantly influenced by the level of development of the acceptor network as well as the labour market situation. The results reaffirm the necessity of developing the card acquiring network, for example with state-led programmes, and highlight the fact that in smaller settlements and less developed regions, card payments are still not sophisticated enough.

Journal of Economic Literature (JEL) codes: G20, D12, R11

Keywords: payments, card acceptance, regional features

\section{Introduction}

Several studies have already extolled the benefits of the spread of electronic payments and the reduction of cash use, both in Hungary and internationally. As shown, for example, in Benedek et al. (2013), macro-level cash demand data are often employed in indirect indicators and assessments used to measure the shadow economy, where transactions typically involve this means of payment. Reducing cash use may curb tax evasion, as confirmed by numerous international papers (e.g. Braithwaite et al. 2002; Rogoff 2017), but other studies concluded that the correlation was not straightforward. According to Seitz et al. (2018), the relationship can only be identified with medium-denomination banknotes

\footnotetext{
* The papers in this issue contain the views of the authors which are not necessarily the same as the official views of the Magyar Nemzeti Bank.

László Kajdi is a Senior Economic Analyst at the Magyar Nemzeti Bank.Email: kajdil@mnb.hu István Nemecskó is a Junior Analyst at the Magyar Nemzeti Bank. Email: nemecskoi@mnb.hu

The Hungarian manuscript was received on 12 September 2019.

DOI: http://doi.org/10.33893/FER.19.1.6589
} 
and smaller, euro-area countries, while a paper by Deutsche Bundesbank (2019) points out that other forms of payment are also used in the shadow economy, and in the case of large denominations the store of value function is much more dominant than various illegal uses. The central bank studies that focused on the high social costs of cash use (Turján et al. 2011; Schmiedel et al. 2012) approached the drawbacks of using cash from a different angle. In the short run, the costs of cash payments are presumably also low, but after a certain critical level their social costs are higher in the long run than in the case of electronic payments.

These factors push government and central bank decision-makers in several countries, including Hungary, towards incentivising the use of electronic payments instead of cash and ensuring the freedom of choice between the forms of payment in all payment situations. It is important to note, however, that in certain countries with low cash use (e.g. Sweden), the latter also means that merchants and banks are required to provide the option for cash payments. As Ilyés - Varga (2015) showed in their study, more than three quarters of retail payment transactions are conducted in cash, which is not substantially different from the experience in most European countries (Esselink - Hernandez 2017), but it indicates that there is still ample room for improvement in this respect. The introduction of instant payments could strongly boost electronic payments in most countries, but currently the biggest rivals to cash in retail transactions are payment cards. The factors influencing their use and acceptance, such as interchange rates and the issue of surcharging have been examined in countless studies in Hungary and abroad (Greene - Stavins 2018; Ilyés - Varga 2018; Jonker et al. 2018; Rochet Tirole 2003).

However, due to a lack of data, until now only a few analyses concentrated on the regional differences in retail payments. Helmeczi (2010) mainly focused on the characteristics of the regional distribution of credit transfers and direct debits as well as the infrastructure (ATMs, POS terminals, bank branches). The availability of bank branches is the lowest in counties Vas, Veszprém and Nógrád, while in Budapest branches are mainly clustered in the central districts. In terms of another service used often by retail customers, ATMs, their share per 1,000 inhabitants is low in the counties Pest and Borsod-Abaúj-Zemplén as well as the Great Plain region, and the coverage of merchants' POS terminals is similar, in which besides the above-mentioned Great Plain region, the counties Nógrád and Szabolcs fare the worst. With respect to credit transfers and direct debit transactions, only interbank transactions carried out through the Hungarian automated clearing house (ACH), GIRO Zrt. were analysed, which obviously provides an incomplete picture, as Hungarian banks' internal items are not included. Other studies (Pál 2014; Kuttor-Pál 2019) also looked at interbank credit transfers and direct debits, but from a network perspective. Based on this, roughly 40 per cent of interbank 
transactions are conducted within settlements, and Budapest plays a special role in the Hungarian payment network, although regional centres can also be identified. In his study, Kovács (2017) analysed the availability and accessibility of branches and also noted the differences between cities and cities with county rights on the one hand and smaller settlements on the other hand. Ilyés - Varga (2015) and Végsö et al. (2018) examined households' account and card ownership as well as payment habits by settlement type. Both of surveys concluded that card coverage and the use of electronic payments was higher in Budapest. The analysis by llyés - Varga (2018) of online cash register data also highlighted the dominance of the capital in terms of card acceptance.

In the approximately ten years that passed since the publication of the study by Helmeczi (2010), the Hungarian payment infrastructure has improved considerably, which entailed a substantial growth in turnover as well, mainly related to payment cards. According to the Magyar Nemzeti Bank (MNB 2019), this was not reflected very strongly in connection with the payment accounts held by natural persons, because the number of accounts was already high at the end of 2010 (at 9.4 million), and therefore only a moderate increase of 3.3 per cent was observed between 2010 and the end of 2018. The situation is similar when it comes to the number of cards held by households, which amounted to 8.7 million retail cards on 31 December 2018, representing growth of 3.9 per cent. With respect to devices, the Hungarian ATM network expanded by 5 per cent, but the number of POS terminals surged sharply, with a more than twofold (117 per cent) increase in the period under review. This also means that card use became much more widespread among households, as the number of card purchases grew by 20-25 per cent annually, and compared to the 198 million purchases in 2010, the 765 million registered in 2018 represent a roughly fourfold expansion.

By European standards, there is still room for improvement in the electronic acquiring network in retail trade. Since currently card payments are basically the only electronic payment method used at physical acceptance points, this can be analysed well using the POS terminal coverage in the different countries. According to European Central Bank data (Figure 1), Hungary ranks in the bottom third in this respect, which presents a tremendous business opportunity for payment service providers. 


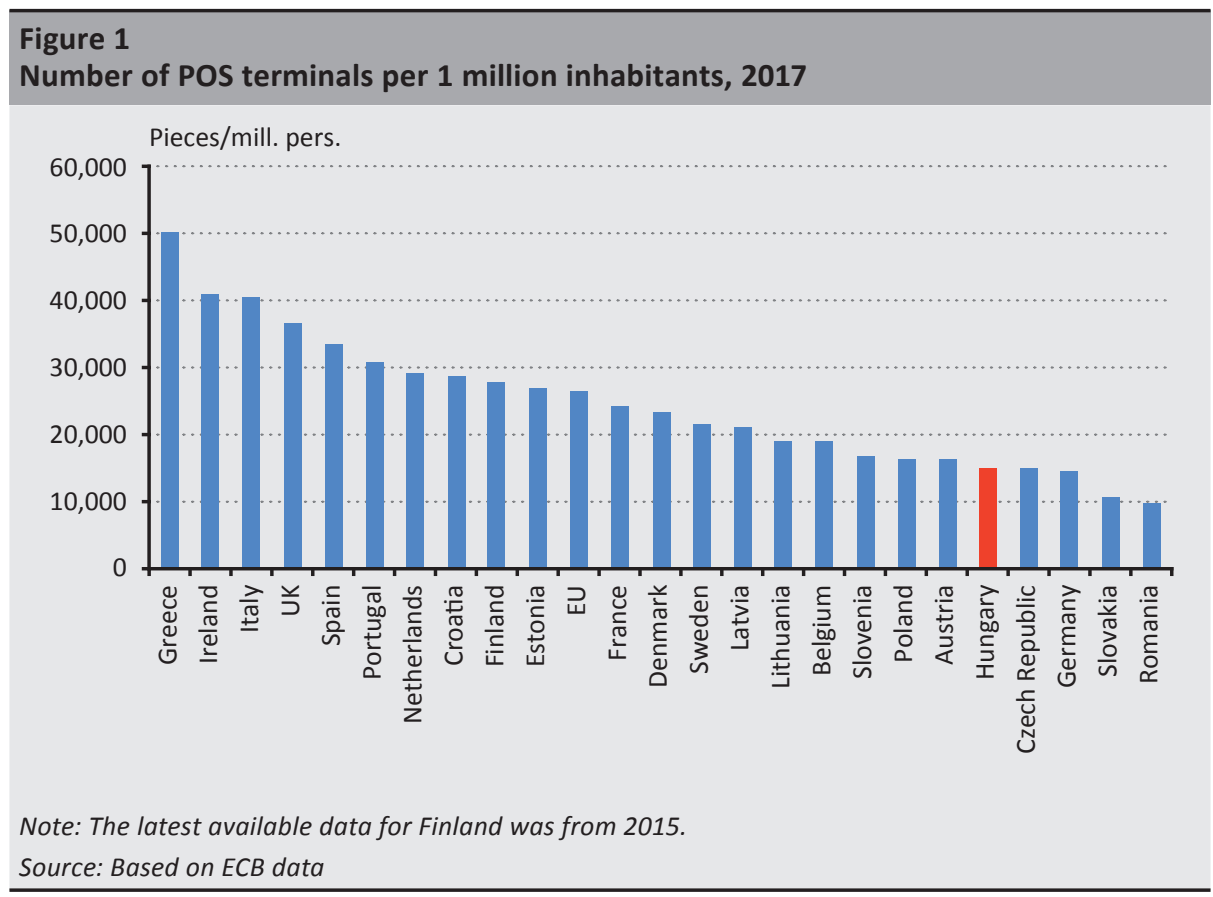

The massive progress in recent years is largely due to the centrally initiated and coordinated programmes, such as the MNB's trial POS terminal deployment programme and the country-wide POS deployment programme of the Ministry of Finance. ${ }^{1}$ On 2 March 2020, major progress was made in the spread of electronic payments in Hungary by the introduction of instant payments under the auspices of the MNB. Since instant payment services may offer an alternative to cash payments in virtually all situations, this could potentially entail a massive expansion of electronic acceptance in retail purchases and the financial settlement of services. This could be driven by market participants that provide acquiring services to merchants, and the development could be considerably supported by further state-run and central bank programmes. However, development activities will only be efficient if the players have a clear picture about payments in Hungary. This also involves taking into account the regional features of Hungarian payments.

The study seeks to assist in this, and present the current situation of the Hungarian payment card infrastructure and turnover from a regional perspective. The novelty of the paper is that no settlement-level data were previously available to analyse the POS network and card turnover as well as the related income of payment service providers. The authors endeavour to use this previously unavailable data

\footnotetext{
${ }^{1}$ Decree No. 47/2016 (XII. 6.) of the Ministry for National Economy on the support provided for increasing the number of bank card terminals
} 
set and paint an broad picture of the regional features of the Hungarian card system, and to identify the factors that impact the development of card payments in Hungary, in particular the acceptor network, card ownership and card turnover, thereby promoting the further development of the Hungarian card system. After presenting the data used, first the characteristics of acquirers and then those of issuers are described along with the explanatory factors of their development, followed by a chapter on card turnover. The study ends with a separate chapter on the summary of the relevant conclusions.

\section{Data used and methodology}

Three main sources of data were used for preparing the analysis. The Hungarian Competition Authority (GVH) began a sector-wide inspection on the bank card acceptance market, requesting settlement-level data from payment service providers offering card acquiring services on POS terminals, specifically the transactions conducted on them and the resulting revenue. This was received by the MNB within the framework of domestic legal assistance, for analysis purposes. The information on the acceptor network is for the reference date of February 2018, while the turnover and revenue data cover the period between 2013 Q1 and the end of 2017. To avoid examining payments in Hungary only from the perspective of the acquirer side and to involve consumers, in other words account holders and cardholders, the region-level data from "What do we live from?", a survey conducted in 2014 by the Hungarian Central Statistical Office (HCSO) commissioned by the MNB, were used. The data are detailed in Simon - Valentiny (2016). These sources of data were complemented with the regional (county- and settlement-level) data of the HCSO (Dissemination database; Counties in focus [Fókuszban a megyék]).

Besides the descriptive analysis of the data, the research questions were examined by linear regression, logistic regression and panel regression, and these models are presented in detail in the next chapters. Due to their detailed information on the regions, the GVH data provide an unprecedented opportunity to meticulously analyse the Hungarian card system, because the MNB's regular payment surveys only contain country-level data. Nevertheless, as noted in the relevant subchapters, the availability of data with the appropriate breakdown (settlementlevel, quarterly) is very limited in other parts of the economy and society, and therefore the low number of explanatory variables may also influence the models where they are incorporated. 


\section{Card acquirer network}

The coverage of the card acquirer network was examined using the number of POS terminals based on GVH data. This was slightly different from the number of places where cards are accepted (typically retailers, accommodation providers and catering establishments), because there can be several terminals at the same acceptance point. Nevertheless, this is an adequate approximation of the regional differences in the acquirer network's coverage. As expected, Budapest fares exceptionally well among the counties in terms of coverage: there are 26 terminals for 1,000 inhabitants, as more than one-third of all the terminals were deployed here (Figure 2). The counties Fejér and Pest also show high values with respect to the number of terminals per 1,000 inhabitants (in the latter, this is mainly attributable to the Budakeszi district, which also includes Budaörs, where a large number of retail establishments are clustered due to the easy access provided by the motorways), while the poorest results came from the counties BorsodAbaúj-Zemplén, Nógrád and Szabolcs-Szatmár-Bereg, where there are hardly over 7 terminals per 1,000 inhabitants.

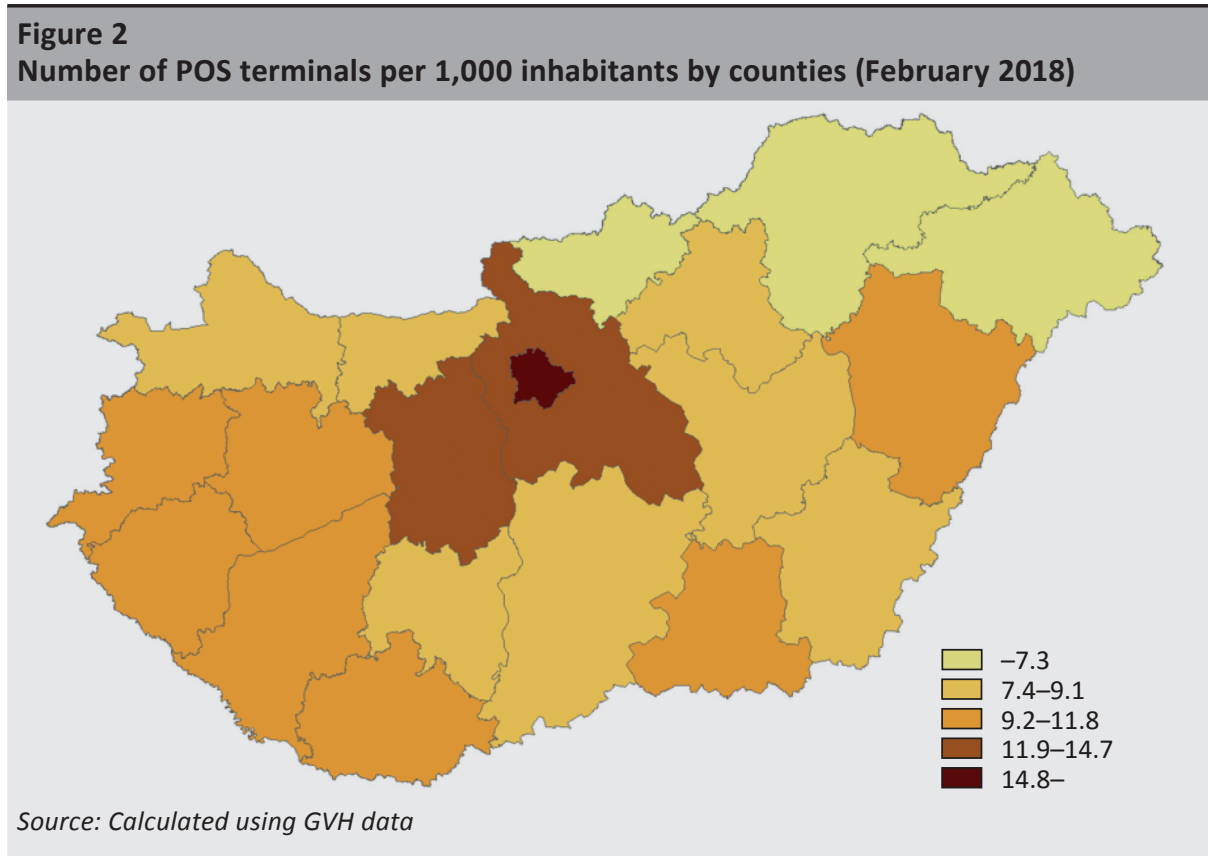

The picture is further nuanced if district-level data are analysed as well (Figure 3). The card payment infrastructure is poorly developed in many districts of the Great Plain. Outside the capital, coverage is the highest in the Budapest metropolitan area and near Lake Balaton, but in line with expectations, the card acceptance 
infrastructure is basically concentrated around cities (Figure 2). Similar regional differences can be identified if the number of POS terminals is compared to the number of companies registered in a region. The number of POS terminals per 1,000 inhabitants was also examined by settlement type. In accordance with the expectations, the ratio was the lowest in villages (4.9) and towns (6.2), while cities (10.2) and cities with county rights (19.3) had somewhat better coverage, which, however, still lagged behind the capital.

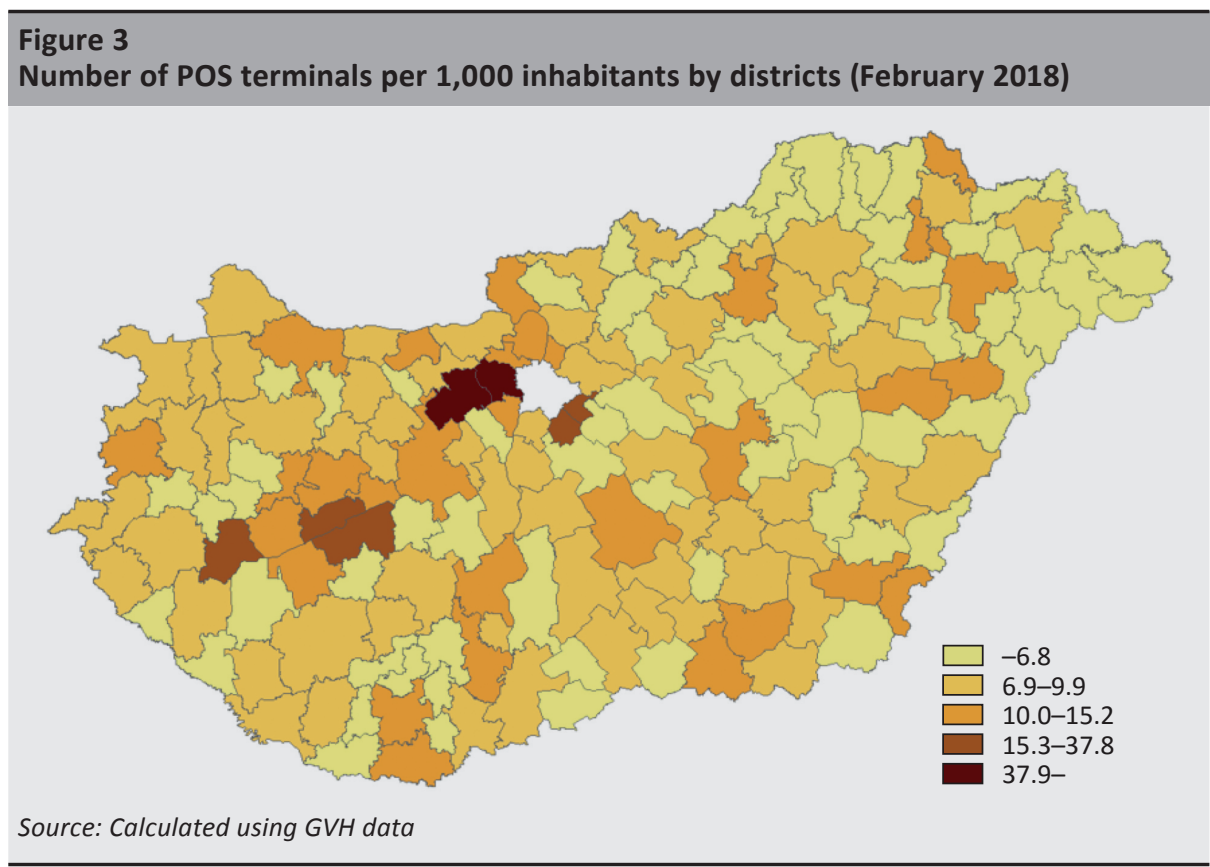

To identify the factors that influence the development of the card acquirer network, linear regression was used to analyse which variables have a significant impact on the number of these devices in the settlements where POS terminals are available. The following variables were taken into account in the regression:

$\log (\mathrm{POS})=\beta_{0}+\beta_{1}$ legcode $+\beta_{2}$ regcode $+\beta_{3}$ compshare $+\beta_{4} \log ($ pop $)+\beta_{5} \log ($ rev $)+\mu$, where

- the dependent variable is:

$-\log (\mathrm{POS})$ : the logarithm of the number of POS terminals in the given settlement

- the explanatory variables are: 
- legcode: the legal status of the given settlement (Budapest and cities with county rights; cities; villages)

- region code

- compshare: the share of companies registered in the accommodation and food service activities and trade sectors of the national economy within all firms

$-\log ($ pop): logarithm of the population of the given settlement

- log(rev): logarithm of the revenues from POS terminals in the given settlement (in other words the profitability of the devices, how much is it worth to deploy them)

\section{Table 1}

Estimated coefficients of the regression explaining the development of the card acquirer network, 2018 Q1

\begin{tabular}{|c|c|}
\hline Variables & Number of POS terminals (log) \\
\hline \multicolumn{2}{|c|}{ Legal status (Budapest and county seats) } \\
\hline Cities & $\begin{array}{l}-0.86 * \\
(-7.12)\end{array}$ \\
\hline Towns & $\begin{array}{c}-1.37^{*} \\
(-10.35)\end{array}$ \\
\hline Villages & $\begin{array}{c}-1.58^{*} \\
(-11.99)\end{array}$ \\
\hline \multicolumn{2}{|c|}{ Regions (Central Hungary including Budapest) } \\
\hline Central Transdanubia & $\begin{array}{l}-0.10^{*} \\
(-1.96)\end{array}$ \\
\hline Western Transdanubia & $\begin{array}{c}-0.09 \\
(-1.82)\end{array}$ \\
\hline Southern Transdanubia & $\begin{array}{c}-0.04 \\
(-0.83)\end{array}$ \\
\hline Northern Hungary & $\begin{array}{l}-0.13^{*} \\
(-2.57)\end{array}$ \\
\hline Northern Great Plain & $\begin{array}{c}-0.03 \\
(-0.67)\end{array}$ \\
\hline Southern Great Plain & $\begin{array}{c}0.00 \\
(0.02)\end{array}$ \\
\hline Share of companies & $\begin{array}{c}2.17 * \\
(12.82)\end{array}$ \\
\hline Population (log) & $\begin{array}{c}0.55^{*} \\
(29.76)\end{array}$ \\
\hline Revenues (log) & $\begin{array}{c}0.20 * \\
(26.29)\end{array}$ \\
\hline Constant & $\begin{array}{l}-1.70^{*} \\
(-7.60)\end{array}$ \\
\hline $\mathbf{R}^{2}$ & 0.86 \\
\hline $\mathbf{N}$ & 2,254 \\
\hline
\end{tabular}

Note: * Coefficients significant at a 95 per cent confidence level, with the values of the $t$-test in brackets. Source: Calculated using GVH and HCSO data 
The results in Table 1 show that as the settlement size diminishes, the number of terminals becomes significantly lower relative to cities; in other words when all other variables are controlled for, the coverage of the acquirer network is lower in smaller settlements. From a regional perspective, terminal coverage is significantly lower, albeit only slightly lower, in Central Transdanubia and Northern Hungary than in the most developed region, Central Hungary, which in this model also includes Budapest. The growing share of companies in retail trade and catering services within all registered firms has a positive impact on the size of the card acquirer network in a given settlement. A similar positive and significant correlation can be observed between population size and the revenues from the terminals. Thus a 1 per cent rise in population numbers boosts the number of POS terminals by 0.55 per cent in a settlement, while a 1 per cent increase in financial service providers' revenue lifts the number of terminals by 0.2 per cent. It should be noted that the model controls for settlement type and settlement size as well, which may be the reason behind the small differences across the regions. The analysis is inhibited by the lack of settlement-level data on retail establishments, so the share of them that accept cards in a given settlement could not be examined. This is especially important because if there is no competition, for example in a smaller settlement with only one retailer, that merchant has less of an incentive to offer card payment.

\section{Household card ownership}

Households' card coverage, in other words the characteristics of card issuers were examined with the data from the first wave of the "What do we live from?" survey. The 72.5 per cent card coverage tallies with the country-level results of llyés Varga (2015), just like the distribution of card ownership by age (Figure 4). It can be stated that in older groups, the ratio of card ownership falls considerably. There are also significant differences in the breakdown by the educational attainment of the head of household: while less than half of those with primary education have a card, the same ratio is 72 and 85 per cent in the case of those with secondary and tertiary education, respectively. When examining coverage by the economic activity of the head of household, the highest ratio (79 per cent) can be found in the case of employees, followed closely by students and housewives with around 75 per cent, whereas the same value for pensioners and the unemployed is much lower (at around 60 per cent). Among students, there are a large number of 25-year-olds, who do not necessarily take part in university education, which can explain that while in the case of those under 20 coverage is approximately 90 per cent, it is lower in the group of all students. 


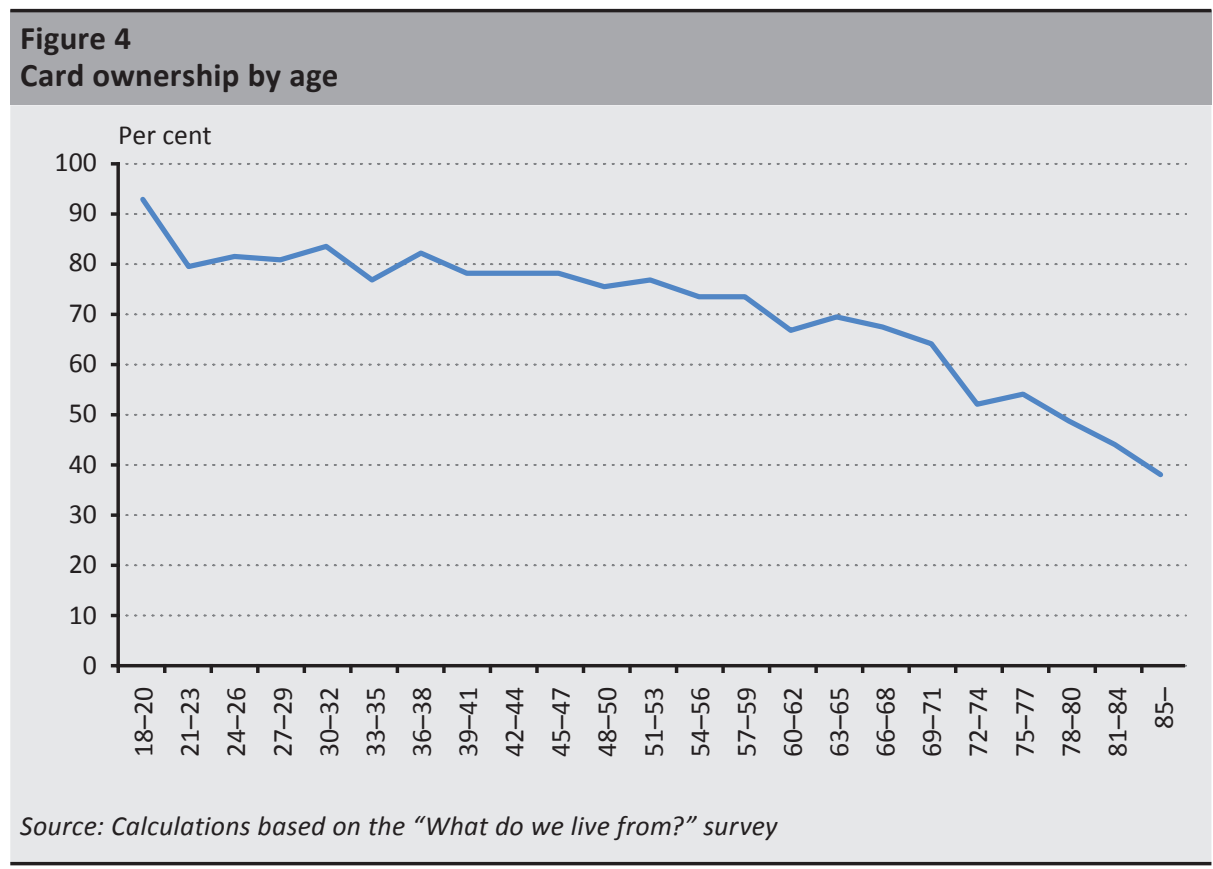

It can be seen, however, that there are major differences across the regions in this respect, with the regions in the Great Plains bringing up the rear, while the situation is the best in Central Hungary. Based on this, there is a roughly 20 percentage point difference in terms of card ownership between the most advanced regions and those that are in the worst shape (Table 2).

\section{Table 2}

Account and card ownership of Hungarian households by regions, 2014

\begin{tabular}{c|c} 
Region & Card coverage (\%)* \\
\hline Central Hungary** & 80.3 \\
\hline Central Transdanubia & 71.8 \\
\hline Western Transdanubia & 75.0 \\
\hline Southern Transdanubia & 70.7 \\
\hline Northern Hungary & 72.0 \\
\hline Northern Great Plain & 61.0 \\
\hline Southern Great Plain & 68.1 \\
\hline Country average & 72.5 \\
\hline
\end{tabular}

Note: * Coverage means that at least one person in the household has an account or payment card.

** The data for Budapest were taken into account among those for Central Hungary.

Source: Calculations based on the "What do we live from?" survey 
Households' payment card coverage was also analysed with logistic regression to identify the factors that influence it. The regression's dependent variable is 1 if there is a bank card in the household, and 0 if there is none. The regression's explanatory variables include regional characteristics, variables describing households' income and social situation as well as the characteristics of the head of household. As can be seen in Figure 4, in the case of heads of household, the share of card ownership declines somewhat more steeply above the age of 60 , and therefore age groups were used to handle this not exactly linear effect. Table 3 shows the odds of the logistic regression, based on which if the odds of the given explanatory variable is under 1 , the probability of card ownership declines, while if it is over 1 , the probability increases. In the model, all explanatory variables had a significant effect at the 95 per cent confidence level examined. The logistic regression is as follows:

$y=\beta_{0}+\beta_{1}$ regcode $+\beta_{2}$ settype $+\beta_{3}$ income $+\beta_{4}$ socbenef $+\beta_{5} \log$ (consum)

$+\beta_{6}$ foodconsum $+\beta_{7}$ utilities $+\beta_{8}$ comp $++\beta_{9}$ gender $+\beta_{10}$ age $+\beta_{11}$ educ

$+\beta_{12}$ econact $+\mu$,

where

- the dependent variable is:

$-\mathrm{y}$ : Whether the household in question owns a bank card (0 or 1)

- the explanatory variables are:

- region code

- settype: type of settlement (Budapest, county seat, town, village)

- income: annual household income per person (under HUF 3 million, HUF 3-5 million, over HUF 5 million)

- socbenef: social benefits in the past 12 months (yes, no)

- $\log$ (consum): logarithm of all consumption expenses

- foodconsum: share of food consumption in total expenses

- utilities: share of utilities spending in total expenses

- comp: Do they have a private enterprise, partnership or other company? (yes, no)

- gender: male, female

- age: 0-29, 30-39, 40-49, 50-59, over 60

- educ: primary, secondary, tertiary educational attainment

- econact: unemployed, student, pensioner, other (gyes, gyed [childcare benefits], sick leave, housewife, disabled) 


\section{Table 3}

Factors shaping the card coverage of households

\begin{tabular}{|c|c|}
\hline Variable & Card ownership \\
\hline \multicolumn{2}{|l|}{ Regions (Central Hungary) } \\
\hline Central Transdanubia & $0.73 *$ \\
\hline Western Transdanubia & $0.85^{*}$ \\
\hline Southern Transdanubia & $0.79 *$ \\
\hline Northern Hungary & $0.78^{*}$ \\
\hline Northern Great Plain & $0.52 *$ \\
\hline Southern Great Plain & $0.75^{*}$ \\
\hline \multicolumn{2}{|l|}{ Settlement type (Budapest) } \\
\hline County seat & $1.39 *$ \\
\hline City & $0.88^{*}$ \\
\hline Village & $0.90^{*}$ \\
\hline \multicolumn{2}{|l|}{ Income and social situation } \\
\hline \multicolumn{2}{|l|}{ Total annual household income per person (under HUF 3 million) } \\
\hline HUF 3-5 million & $1.06^{*}$ \\
\hline over HUF 5 million & $1.46^{*}$ \\
\hline Social benefits in the past 12 months (yes) & $0.75^{*}$ \\
\hline Logarithm of all consumption expenses (HUF) (log) & $1.71 *$ \\
\hline Share of food consumption in total expenses & $1.20 *$ \\
\hline Share of utilities spending in total expenses & $1.37^{*}$ \\
\hline Do they have a private enterprise, partnership or other company? (no) & $0.74 *$ \\
\hline \multicolumn{2}{|l|}{ Characteristics of the head of household } \\
\hline Gender (female) & $1.05^{*}$ \\
\hline \multicolumn{2}{|l|}{ Age (0-29) } \\
\hline $30-39$ & $0.90 *$ \\
\hline $40-49$ & $1.11^{*}$ \\
\hline $50-59$ & $0.92 *$ \\
\hline over 60 & $0.50^{*}$ \\
\hline \multicolumn{2}{|l|}{ Educational attainment (primary) } \\
\hline Secondary & $2.04^{*}$ \\
\hline Tertiary & $3.53^{*}$ \\
\hline \multicolumn{2}{|l|}{ Economic activity (employee) } \\
\hline Unemployed & $0.78^{*}$ \\
\hline Student & $4.31 *$ \\
\hline Pensioner & $0.96^{*}$ \\
\hline Other (gyes, gyed [childcare benefits], sick leave, housewife, disabled) & $0.66^{*}$ \\
\hline Cons & $0.22 *$ \\
\hline $\mathrm{N}$ & 6,049 \\
\hline \multicolumn{2}{|l|}{ Note: * Significant at a confidence level of 95 per cent. } \\
\hline
\end{tabular}


From a regional perspective, the probability of card ownership is lower in all regions than in Central Hungary, with the situation the worst in the Northern Great Plain, which confirms the descriptive data. Kuttor - Pál (2019) examined the regional distribution of bank branches. According to their results, card ownership and the distribution of branches show a similar pattern, which might be worth examining in the future. As regards settlement types, compared to Budapest, card ownership is significantly more likely in county seats and less likely in other cities and villages. This may be attributable to the fact that the payment infrastructure is typically less developed in these latter settlement types, as shown in the previous chapter, and therefore cards can be used in fewer places, which has a negative impact on ownership as well. Categories were used in the per capita income of households, and based on that the probability of card ownership increases in tandem with income. The results also show that card ownership is slightly lower in the households that receive social benefits (e.g. family allowance, gyed, gyes [childcare benefits], other benefits and allowances). With respect to consumption, card coverage is higher in households in a better financial situation, even if examining the share of spending on food and utilities within total consumption. The gender of the head of household influences card ownership at the household level only to a very limited degree. In the case of female heads of household, the ratio is somewhat higher. As regards age, compared to young adults (under 30 ), the likelihood of card ownership was lower in all other age groups, except for those aged 40-49. Card coverage is especially low in the age cohort of pensioners. This is consistent with the results of Ilyés - Varga (2015) regarding individual-level surveys, which also showed the largest drop in card coverage among those aged over 60 . Educational attainment produces similar results: card ownership is significantly higher among graduates (according to the model, this variable exerts the greatest impact), and this confirms the conclusions of the earlier study. This also ties in with the fact that according to Végsö et al. (2018), there is a negative correlation between cash payment and educational attainment. In the case of those receiving gyes [childcare benefit], on sick leave, the disabled, the unemployed and pensioners, the probability of card ownership is significantly lower than in the case of employees, whereas it is higher in the case of students. The latter is probably attributable to the fact that this age group prefers electronic payment methods to cash. Moreover, most students over 18 take part in tertiary education, where having a bank account and bank card is essential, which may also explain the exceptionally high card ownership figures. 


\section{Card use}

The regional distribution of card turnover should be analysed with transactions per POS terminal, taking into account the spatial differences in the acceptor infrastructure, in other words basically examining how actively cardholders use the established card acceptance network. Data are only available on the value of transactions rather than their number, which slightly distorts the regional comparison. This is because card payments are mostly widespread in retail trade and services, and there can be differences across the different districts in their price levels (Figure 5). Based on the descriptive data, the regional distribution of transactions is much more concentrated than that of the acquirer network, and intensive card use is mostly seen in cities and the northwestern part of the country, attributable to the level of economic development in the Budapest metropolitan area, tourism in the Balaton Uplands and the industrial centres near the western border. At the same time, turnover in the territories near the eastern border is low despite the relatively well-developed POS network. ${ }^{2}$

\section{Figure 5}

Turnover value of card purchases per POS terminal by districts (HUF thousand, 2017 Q4)

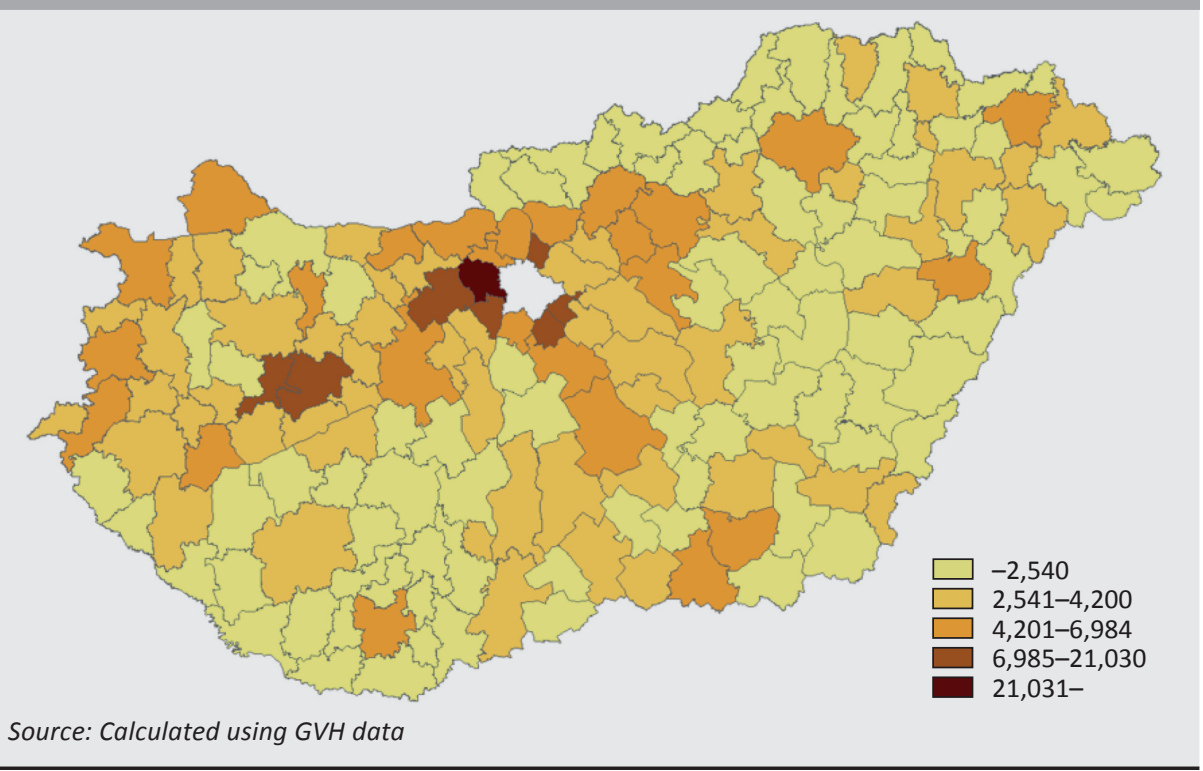

\footnotetext{
${ }^{2}$ The outstanding value for District Budaörs may be explained by the large turnover generated by the retail stores near the motorways leading into the capital, while in the case of District Bicske, the data is probably distorted due to the centre of a large retail chain.
} 
It should be noted that card transactions are influenced by several factors, for example the size of the retail trade and catering sector in the given area or the level of development of the acquirer network. Another important factor is the role of cardholders (issuers), in other words the share of card ownership within the population (which was presented in the previous chapter) and how actively cardholders use their existing cards for payments. Comparing card turnover to the population of the given area can provide a detailed picture about this (Figure 6). The comparison shows that card payments are used more actively by those living in cities (which, of course, may be connected to the level of development of the acquirer side).

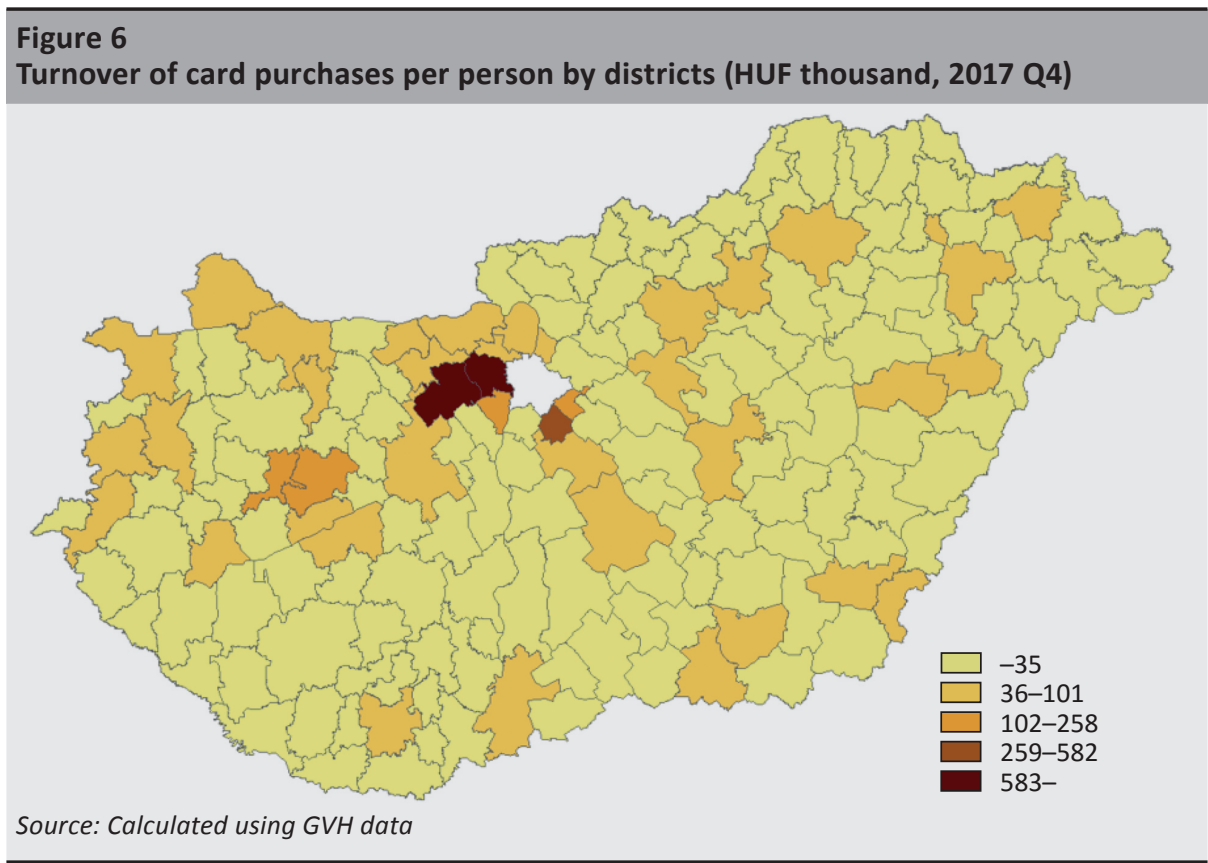

The analysis of the profitability of the deployed POS terminals, i.e. the revenue of payment service providers per terminal (which merchants see as a cost) yields similar results (Figure 7). This is mainly related to the fact that most payment service provider fees are value-based: more turnover means more revenues. When adjusting for turnover data as well by dividing revenue figures with them, it can be seen that in Eastern Hungary and Southern Transdanubia, which are less developed from the perspective of the card infrastructure, providing card acceptance services is generally much more expensive for merchants. However, this is presumably not due to the different price setting of payment service providers but rather to the fact that the retail trade sector has a different structure in these areas, and the share of larger merchants who have more bargaining power and consequently use cheaper card acceptance services is much lower. And in the case of smaller 
merchants, payment service provider fee costs are recovered much slower on account of the lower turnover.

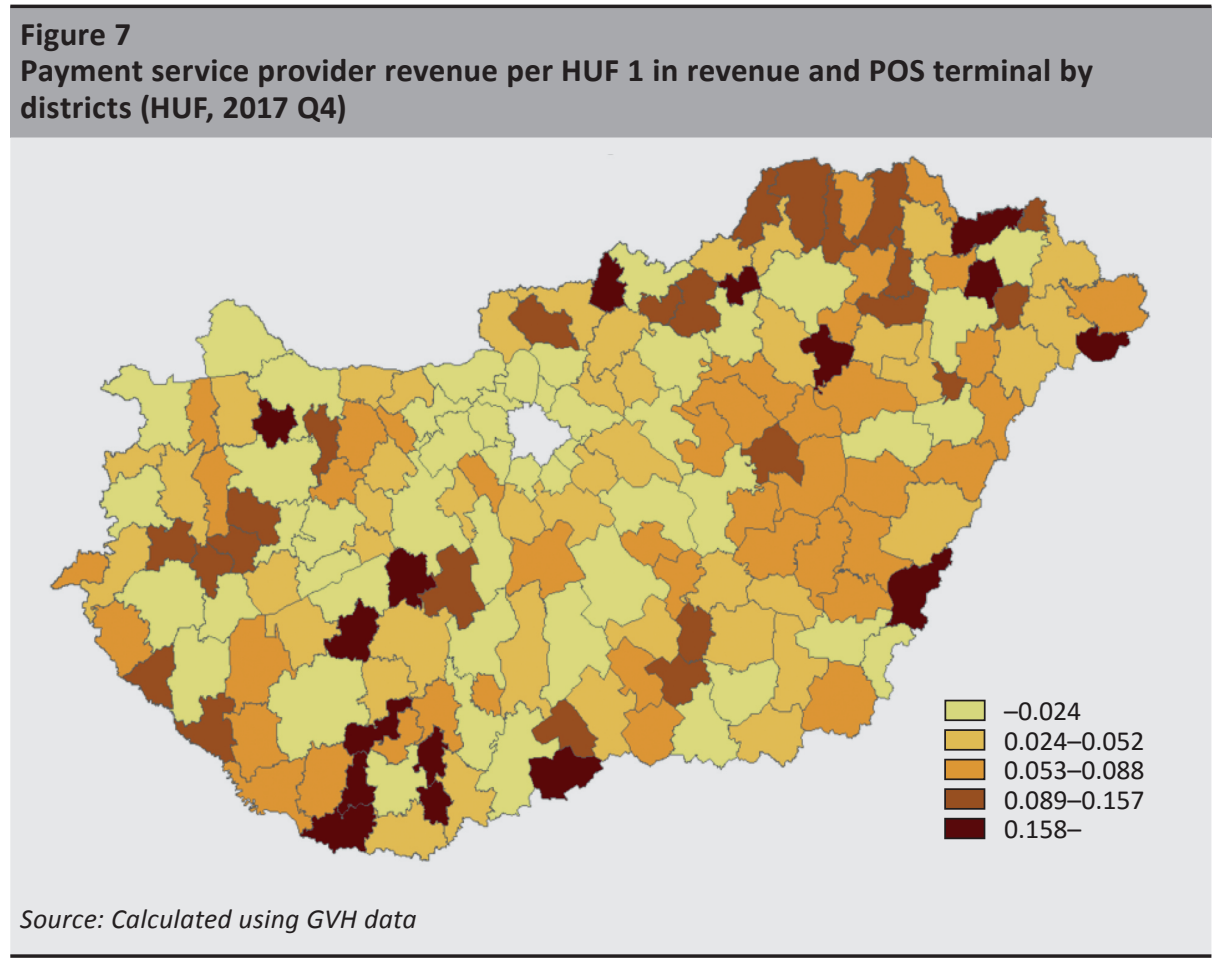

The factors influencing card use were analysed with several methods, because just as in the case of the acceptor network, the limited number of the available settlement-level explanatory variables is a problem in the case of turnover, too. Three main factors can influence card turnover:

- The development level of the acquirer network. Whether there are enough terminals so that card payment is available to those who want to use it (the characteristics of this were investigated in Chapter 1).

- Features of the card issuer or cardholder side. The number of customers who are potential card users and their socio-demographic composition; the share of card ownership in the population; customer preferences (the characteristics of this were investigated in Chapter 2). In their paper, Végső et al. (2018) studied the reasons behind customers' choice between electronic and cash payments. Further research should be conducted based on this. The results may serve as another yardstick for the measures aimed at expanding card acceptance, possibly even differentiated by regions. According to the study, the volume 
of card and electronic payments can be increased not only by broadening the acceptor network but also by other promotional measures. This may be especially effective in the case of instant payments, which will be launched on 2 March 2020.

- The overall level of economic development and profile of the region. The development of retail sales, the role of the retail trade and catering services sector (the role of tourism), where card acceptance is the most typical, in the economy of the region. The limitation of the models is that no data with the necessary level of detail were available on the overall development of retail sales, and therefore this factor could not be incorporated.

First, linear regression was used for 2018 Q1 to examine card turnover at the settlement level, because POS network data are only available for one date (February 2018). Besides the data on the acquirer network, the HCSO's settlementlevel data were employed. The following model was analysed, stripped from the explanatory variables without a significant effect: ${ }^{3}$

$$
\begin{aligned}
\log (\text { turnov })= & \beta_{0}+\beta_{1} \log (\mathrm{POS})+\beta_{2} \log (\text { net })+\beta_{3} \text { compshare }+\beta_{4} \text { legcode } \\
& +\beta_{5} \text { unempshare }+\mu,
\end{aligned}
$$

where

- the dependent variable is:

log(turnov): the logarithm of the total card turnover (value) in the given settlement

- the explanatory variables are:

- the features of the acceptor network:

$\log (\mathrm{POS})$ : the logarithm of the number of POS terminals in the given settlement

- indicators of the overall level of economic development:

$\log ($ net): the logarithm of the number of Internet subscriptions in the given settlement

compshare: the share of companies registered in the accommodation and food service activities and trade sectors of the national economy within all firms

- regional characteristics:

legcode: the legal status of the given settlement (Budapest and cities with county rights; cities; villages)

- characteristics of the cardholder side:

unempshare: the share of the unemployed (relative to 15-64-year-olds) in the given settlement.

\footnotetext{
${ }^{3}$ Such variables include the regional variable or the share of those aged over 65 within the total population.
} 


\begin{tabular}{|c|c|}
\hline \multicolumn{2}{|c|}{$\begin{array}{l}\text { Table } 4 \\
\text { Estimated coefficients of the regression explaining card turnover, } 2018 \text { Q1 }\end{array}$} \\
\hline Variables & Card turnover value (log) \\
\hline Number of POS terminals (log) & $\begin{array}{l}1.62^{*} \\
(2.57) \\
\end{array}$ \\
\hline Ratio of internet subscriptions to total population & $\begin{array}{l}6.23^{*} \\
(8.45) \\
\end{array}$ \\
\hline Share of companies & $\begin{array}{l}20.60^{*} \\
(12.14)\end{array}$ \\
\hline \multicolumn{2}{|l|}{ Legal status (Budapest and county seats) } \\
\hline Cities & $\begin{array}{l}0.92^{*} \\
(2.34) \\
\end{array}$ \\
\hline Villages & $\begin{array}{c}0.41 \\
(0.96) \\
\end{array}$ \\
\hline Ratio of the unemployed & $\begin{array}{l}-7.20^{*} \\
(-7.15) \\
\end{array}$ \\
\hline Constant & $\begin{array}{c}-2.67^{*} \\
(3.98) \\
\end{array}$ \\
\hline $\mathbf{R}^{2}$ & 0.62 \\
\hline N & 2,260 \\
\hline
\end{tabular}

The results show that a more developed acceptor network does significantly contribute to the expansion in card turnover, and so the development of infrastructure should be supported to reduce the use of cash. From the perspective of infrastructure, increasing Internet penetration also has a positive effect, although this is rather a general economic indicator in the present model. The effect of the acquirer network and the overall economic situation of a region is shown by the fact that the larger the number of companies registered in the retail trade, accommodation and catering services sectors, the more active the card use. Card use is lower in towns and villages than in cities, which is consistent with the descriptive results described above (Figure 4-5) and the studies by llyés - Varga (2015) and Végsö et al. (2018). On the cardholder side, an increase in the number of unemployed can negatively influence card turnover, which corresponds with the result presented in Chapter 4 that card ownership is lower among those with a more disadvantaged social background.

The factors influencing card turnover were examined not only with linear regressions but also with panel regressions, as turnover data are available from 2013 Q1 until 2017 Q4, making 20 periods in total. The panel regressions were run at the county level, because there are more explanatory variables available for this territorial level than for settlements. The explanatory variables used in the linear regression (Table 4) were complemented (while keeping the dependent variable, 
the logarithm of card turnover, constant) with the examination of the effect of the educational attainment of registered jobseekers, i.e. the share of those with primary, secondary and tertiary education among all jobseekers.

\begin{tabular}{l|c}
\hline \multicolumn{1}{c}{$\begin{array}{l}\text { Table } 5 \\
\text { Results of the county-level panel regressions, 2013 Q1-2017 Q4 }\end{array}$} & Card turnover (log) \\
\hline Ratio of employees to total population & $6.06^{*}$ \\
& $(6.06)$ \\
\hline Net average monthly wage (log) & $1.46^{*}$ \\
& $(12.87)$ \\
\hline Ratio of the unemployed to total population & $-6.81^{*}$ \\
& $(-5.99)$ \\
\hline Number of overnight stays in commercial & $0.16^{*}$ \\
accommodation establishments (log) & $(9.69)$ \\
\hline Constant & $-4.32^{*}$ \\
& $(-3.44)$ \\
\hline $\mathrm{R}^{2}$ & 0.85 \\
\hline Note: * Coefficients significant at a 95 per cent confidence level, with the values of the t-test in brackets \\
Source: Calculated using GVH and HCSO data \\
\hline
\end{tabular}

The results of the panel analysis (Table 5) bear out the conclusions of the crosssectional analysis, namely that the labour market conditions of a region significantly influence the development of card turnover. Furthermore, a significantly positive correlation was demonstrated with income and overnight stays, and thus higher wages and a greater number of guests boost card payments.

\section{Cluster analysis}

The point of cluster analysis is to classify the data based on the available variables to gain additional information. The algorithm groups together settlements that are the closest to the same mean based on the available data. In this case, more information is sought on how to classify the settlements based on the characteristics of card payments, using card turnover and the number of POS terminals. Clustering was performed for 2-6 groups, and it was found that the optimal number of clusters is 4 . The results of this analysis are presented below. The characteristics of certain settlements differ markedly from the others, producing outliers, and therefore they were excluded from the analysis. Examples of this include Budapest and settlements with no POS terminals. The remaining settlements can be classified into four distinct groups.

After the outliers are managed, $k$-means clustering divides the remaining 2,439 data points (settlements) into four stable and distinct clusters. The smallest of 
the four stands wide apart from the others. Containing eight elements, this group is distinct from the other data points even if fewer clusters are used. This fourth group contains the largest cities: Székesfehérvár, Debrecen, Nyíregyháza, Győr, Pécs, Kecskemét, Miskolc and Szeged. It is characterised by relatively large card turnover coupled with an extensive acceptor network. Kuttor-Pál (2019) reached a similar conclusion examining 2017 data. Their paper, which created clusters based on total turnover, showed that the same eight county seats stood out from the settlements under review. Group 3 is also characterised by large turnover, but the number of POS terminals is much lower (585 on average) than in Group 4. It includes the county seats that did not make it into Group 4 and larger, more developed cities. ${ }^{4}$ Group 1 comprises the less developed larger cities that are missing from the previous two groups, and the developed towns. This group is characterised by an average number of POS terminals (around 163) and average turnover. Group 2, consisting of small towns and the smallest settlements, is also markedly distinct. Since the settlements with zero POS terminals were filtered out in advance, this group includes the small settlements where POS terminals are present, albeit in low numbers (nine on average), and turnover is also substantially lower than in the other groups (Table 6).

\section{Table 6}

Settlement clusters created based on the features of card payments

\begin{tabular}{c|c|c|c}
$\begin{array}{c}\text { Cluster } \\
\text { number }\end{array}$ & Size of group & $\begin{array}{c}\text { Number of POS terminals } \\
\text { deployed }\end{array}$ & Logarithm of card turnover \\
\hline $\mathbf{1}$ & 118 & 163.5 & 14.4 \\
\hline $\mathbf{2}$ & 2,284 & 9.5 & 8.7 \\
\hline $\mathbf{3}$ & 29 & 585.8 & 16.2 \\
\hline $\mathbf{4}$ & 8 & $1,852.6$ & 17.6 \\
\hline
\end{tabular}

Source: Calculated using GVH data

The analysis showed that the settlements can be classified into distinct groups based on the chosen variables. Settlements of the same size and level of development were grouped together based on the number of POS terminals and card turnover, which means that they have roughly the same number of POS terminals and card turnover. The clusters are distinct, so the settlements in the different groups vary based on the variables under review (Annex, Figure 8). Using the approach described above, a cluster analysis based on prorated variables should also be conducted to facilitate the identification of the smaller but more developed settlements. Settlements without a POS terminal were excluded here

\footnotetext{
${ }^{4}$ Szombathely, Veszprém, Szolnok, Eger, Békéscsaba, Siófok, Kaposvár, Sopron, Zalaegerszeg, Tatabánya, Budaörs, Üllő, Érd, Dunakeszi, Gödöllő, Pápa, Ajka, Dunaújváros, Nagykanizsa, Szekszárd, Gyöngyös, Salgótarján, Hajdúszoboszló, Gyula, Baja, Hódmezővásárhely.
} 
as well. In this approach, a 4-mean cluster analysis was prepared for the following variables: number of POS terminals per 1,000 people, card turnover per person, turnover per POS terminal. This divides the sample under review into a small group, a medium group and a large group based on the number of data points.

\section{Table 7}

Settlement clusters created based on the prorated features of card payments

\begin{tabular}{c|c|c|c|c}
$\begin{array}{c}\text { Cluster } \\
\text { number }\end{array}$ & Size of group & $\begin{array}{c}\text { Average number of } \\
\text { POS terminals per } \\
\mathbf{1 , 0 0 0} \text { people }\end{array}$ & $\begin{array}{c}\text { Average card } \\
\text { turnover per } \\
\text { person }\end{array}$ & $\begin{array}{c}\text { Average turnover } \\
\text { per POS terminal }\end{array}$ \\
\hline $\mathbf{1}$ & 6 & 9.0 & $1,284.4$ & $162,919.2$ \\
\hline $\mathbf{2}$ & 5 & 18.1 & $11,167.6$ & $607,041.0$ \\
\hline $\mathbf{3}$ & 2,104 & 5.9 & 27.9 & $3,877.3$ \\
\hline $\mathbf{4}$ & 324 & 9.7 & 247.5 & $24,556.7$ \\
\hline
\end{tabular}

Source: Calculated using GVH data

The first two groups are easy to distinguish. Group 2 is characterised by a developed card system, i.e. a relatively high number of POS terminals, and high turnover per person and per POS terminal (see Table 7). In Group 1, the number of POS terminals per 1,000 people is lower, while the turnover per person and per POS terminal are high, so card use is more active than warranted by the level of development of the acceptor network. In other words, this is the group of settlements with relatively few POS terminals that generate large turnover. Group 3, the largest cluster, includes small and less developed settlements with low POS coverage and low turnover. Group 4 contains settlements with a relatively large number of POS terminals and low turnover. Despite the advanced acceptor network, the terminals are used less frequently due to other reasons, for example low retail sales, less broad shop chains or the low share of cardholders.

Group 2 includes: Törökbálint, Biatorbágy, Budaörs, Alsónémedi and Bicske. The first three are among the most developed settlements in the country, so the high POS terminal coverage and turnover come as no surprise. As noted above, Bicske and Budaörs most likely made it into this group owing to their favourable location, which tallies with the analysis by Kuttor - Pál (2019). They are preferred shopping destinations for many people living in Budapest, thanks to their proximity to the capital and the abundance of shopping centres. This may explain the high number of POS terminals and the huge turnover. 


\section{Conclusions}

The study sought to provide a detailed picture of the features of the Hungarian card network and turnover using previously unavailable data. Whereas - barring a few exceptions - until now the MNB has primarily examined the characteristics of Hungarian payments at the country level, the database used in this analysis allowed even settlement-level traits to be captured. The paper is envisaged to facilitate the continued spread of electronic payment methods in Hungary, which may even go beyond card use. The results may contribute to the further spread of future instant payment solutions, since the new, transfer-based payment method may prove to be a cheaper electronic acceptance alternative, especially for smaller firms currently less involved in card acquiring. The results on the development of the card acceptance network attest that there are large regional differences in the country, and card acceptance is particularly low in the eastern areas that are far away from cities. As proven by the MNB's data, this is attributable to the fact that this service is much more expensive relative to turnover in the case of smaller retail outlets, largely because this is how banks manage the higher risk associated with the segment of smaller merchants. This is where the appearance of instant payments could be very important, as it may contribute massively to the development of the regions in Northern Hungary and the Great Plain as well as that of smaller villages, which are less developed from a payment perspective. The continuation and expansion of the public POS deployment programme could be similarly beneficial, and the provision of an electronic payment option may be required from a predetermined and steadily growing group of commercial acceptance points.

The conclusions of this study on households' card ownership confirm the results of the latest MNB survey of this topic conducted in 2014 (Ilyés - Varga 2015). Households' card coverage is significantly influenced by the educational attainment, age and social situation of the head of household. However, due to the larger sample size compared to the earlier survey, the regional characteristics could be examined in more detail. The results confirm the initial expectations, namely that the Central Hungary region including Budapest is the most advanced in this regard, while those living in the Northern Great Plain fare the worst. When it comes to settlement types, households' card coverage is lower in villages and smaller towns than in Budapest, but the differences are smaller compared to the earlier analysis in that based on the database analysed here, this ratio is higher in county seats than in the capital.

The strong degree of concentration around cities and major tourist destinations in the acceptor network can also be traced in card turnover. The capital and Northwestern Hungary should be highlighted as the areas with the most active card use. The analysis showed that the expansion of the acquirer network significantly boosts card turnover, which demonstrates, among other things, the importance of the countrywide POS terminal deployment programmes launched by the Ministry of Finance. 
Another aspect worth mentioning is the effect of labour market factors, because the share of unemployed and employees significantly influences card turnover. This may point on the one hand to the importance of the cardholder (issuer) side, and on the other hand to the overall level of economic development of the different areas.

As indicated above, the relatively low number of explanatory variables available in the appropriate breakdown that could be incorporated into the models inhibited the analysis. Therefore a subsequent, repeated regional analysis could greatly improve the results if the currently available data set expands, for example with settlement-level data on income, retail sales or the number of card payments. In the future, the data from online cash registers and the surveys could provide new and relevant information, which can be used to produce even more accurate results. And while this analysis allowed only a cross-sectional examination of the regional features of the card acceptor network, any new reporting could open the way to showing the changes in the features over time.

\section{References}

Benedek, D. - Elek, P. - Köllö, J. (2013): Tax Avoidance, Tax Evasion, Black and Grey Employment. In: Fazekas, K. - Benczúr, P. - Telegdy, Á. (eds.): The Hungarian Labour Market, Review and Analysis. Institute of Economics, Hungarian Academy of Sciences, Budapest.

Braithwaite, V. - Schneider, F. - Reinhart, M. - Murphy, K. (2002): Charting the Shoals of the Cash Economy. In: Braithwaite, V. (ed.): Taxing Democracy. Ashgate Publishing Ltd.

Deutsche Bundesbank (2019): Cash demand in the shadow economy. Deutsche Bundesbank Monthly Report March 2019.

Esselink, H. - Hernandez, L. (2017): The use of cash by households in the euro area. ECB Occasional Paper Series No. 201, European Central Bank.

European Central Bank (ECB): Statistical Data Warehouse, Number of POS terminals per million inhabitants. Downloaded: 29 July 2019.

Greene, C. - Stavins, J. (2018): The 2017 Diary of Consumer Payment Choice. Research Data Reports No. 18-5, Federal Reserve Bank of Atlanta.

Helmeczi, I. (2010): A magyarországi pénzforgalom térképe (The map of payments in Hungary). MNB Occasional Papers 84, Magyar Nemzeti Bank.

Ilyés, T. - Varga, L. (2015): Show me how you pay and I will tell you who you are - Sociodemographic determinants of payment habits. Financial and Economic Review, 14(2): 25-61. https://en-hitelintezetiszemle.mnb.hu/letoltes/2-ilyes-varga-en.pdf

Ilyés, T. - Varga, L. (2018): Acceptance of Payment Cards by Retailers in Hungary Based on Data of Online Cash Registers. Financial and Economic Review, 17(1): 83-109. http://doi. org/10.25201/FER.17.1.83109 
Jonker, N. - Hernandez, L. - de Vree, R. - Zwaan, P. (2018): From cash to cards: how debit card payments overtook cash in the Netherlands. N.V. Occasional Studies Volume 16-1, De Nederlandsche Bank.

Kovács, S. Zs. (2017): Város-vidék-kapcsolat a magyar pénzintézet-hálózatban (Urban-rural relationship in the Hungarian financial institution network). Területi Statisztika, 57(5): 495-511.

Kuttor, D. - Pál, Zs. (2019): A hazai fizetési forgalom területi aspektusa (The spatial aspect of payments in Hungary). Területi Statisztika, 59(1): 49-68. https://doi.org/10.15196/ TS590103

MNB (2019): Pénzforgalmi táblakészlet (Payment tables). Magyar Nemzeti Bank. Downloaded: 6 June 2019.

Pál, Zs. (2014): A magyarországi bankközi klíringrendszer müködésének vizsgálata az elszámolás modernizációjának tükrében (Analysis of the Hungarian clearing system's operation in the light of the settlement modernisation). PhD thesis, University of Miskolc, Faculty of Economics, Enterprise Theory and Practice Doctoral School.

Rochet, J.-Ch. - Tirole, J. (2003): An Economic Analysis of the Determination of Interchange Fees in Payment Card Systems. Review of Network Economics, 2(2): 69-79. https://doi. org/10.2202/1446-9022.1019

Rogoff, K. S. (2017): The curse of cash. Princeton University Press. https://doi.org/10.2307/j. ctvc77m90

Schmiedel, H. - Kostova, G. - Ruttenberg, W. (2012): The social and private costs of retail payment instruments. ECB Occasional Paper Series No. 137, European Central Bank.

Seitz, F. - Reimers, H. - Schneider, F. (2018): Cash in Circulation and the Shadow Economy: An Empirical Investigation for Euro Area Countries and Beyond. CESifo Working Paper Series 7143, CESifo Group Munich.

Simon, B. - Valentiny, Á. (2016): Miből élünk? Az első átfogó hazai háztartási vagyonfelmérés bemutatása (What do we live from? An overview of the first comprehensive Hungarian household wealth survey). Statisztikai Szemle (Hungarian Statistical Review), 94(7): 717735. https://doi.org/10.20311/stat2016.07.hu0717

Turján, A. - Divéki, É. - Keszy-Harmath, Z. - Kóczán, G. - Takács, K. (2011): Semmi sincs ingyen: A föbb magyar fizetési módok társadalmi költségének felmérése (Nothing is free: A survey of the social cost of the main payment instruments in Hungary). MNB Occasional Papers 93, Magyar Nemzeti Bank.

Végső, T. - Belházyné Illés, Á. - Bódi-Schubert, A. (2018): Készpénz vagy kártya? A magyar lakosság fizetési szokásainak feltáró elemzése (Cash or card? An Explorative Analysis of Consumers' Payment Behaviour in Hungary). Pénzügyi Szemle (Public Finance Quarterly), 2018(4): 448-472. 


\section{Annex}

\section{Figure 8}

Settlement clusters created based on the features of card payments

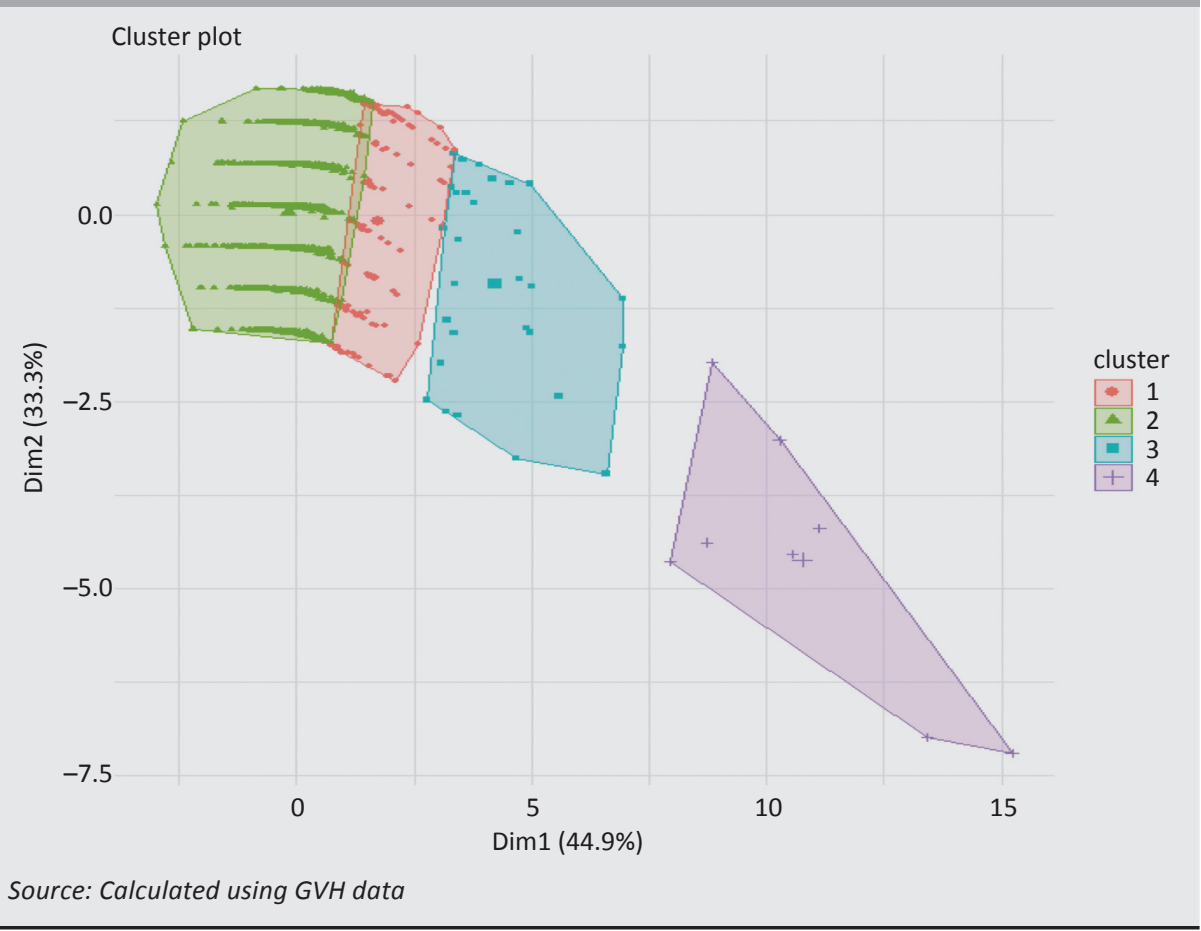

